\title{
PENGARUH AGING DAN LOKASI OTOT TERHADAP KUALITAS ORGANOLEPTIK DAGING SAPI
}

\author{
Harapin Hafid H dan Adnan Syam'
}

\section{INTISARI}

Penelitian ini bertujuan untuk mengetahui pengaruh lama pelayuan dan jenis otot terhadap kualitas arganoleptik daging sapi. Perlakuan adalah lama pelayuan dengan taraf ; A1 (lama pelayuan 0 hari), $\mathrm{A} 2$ (lama pelayuan tiga hari), A3 (lama pelayuan empat hari), A4 (lama pelayuan lima hari), dan A5 (tama pelayuan enam hari) dan jenis otot dengan taraf: B1 (otot Longissimus dorsi $=1 . D$ ), B2 (otot Semitendinosus $=S T$ ), B3 (otot Pectoralis propundus $=P P$ ). Hasil penelitian menunjukkan bahwa lama pelayuan enam hari dengan otot Longissimus dorsi menunjukkan kualitas organoleptik yang lebih baik pada parameter keempukan, warna, cita rasa dan kesan jus daging.

(Kata kunci: Pelayuan, Jenis otot, Kualitas daging)

Buletin Peternakan 31 (4): 209-216, 2007

\footnotetext{
'Jurusan Produksi Ternak Faperta Universitas Haluoleo, J. E.A. Mokodompit no.9 Kampus
} Tridharma Kendari Sulawesi Tenggara 93232 


\title{
THE EFFECT OF AGING ON BEEF MUSCLE QUALITY
}

\begin{abstract}
The research was conducted to see the aging time on meat tenderness of certain type of muscle. There were five levels of aging time namely $\mathrm{A} 1$ ( 0 day of aging), A2 (three days of aging), A3 (four days of aging), A4 (five days of aging), A5 (five days of aging). There were three types of muscle namely Longissimus dorsi (LD/B1), Semitendinosus (ST/B2), and Pectoralis propundus (PP/B3). The result showed that organoleptic quality on tenderness, color, taste as well as juiceness was best on Longissimus dorsi muscle with six days aging.
\end{abstract}

(Key words : Aging, Musele type, Meat quality)

\section{Pendahulnan}

Keragaman karakteristik karkas dan daging sapi Bali dipengaruhi oleh beberapa faktor seperti kualitas pakan, cara pemeliharaan, metode penyembelihan, sanitasi lingkungan, aplikasi perangsang tumbuh dan zat perangsang keempukan daging. Di Sulawesi Tenggara pemeliharaan ternak khususnya sapi Bali masih dilakukan secara tradisional yaitu pemberian pakan sangat tergantung pada keterscdiaan rumput alam atau hijauan disekitarnya lahan pertanian. Hal ini secara tidak langsung mempengaruhi kualitas karkas yang dihasilkan.

Faktor kualitas daging ditentukan oleh keempukan, warna, flavour atau cita rasa termasuk bau dan cita rasa serta kesan jus daging (juiciness). Faktor kualitas daging tersebut merupakan sebagian sifat mutu yang menentukan pencrimaan konsumen terhadap daging, terutama keempukannya sangat tergantung pada bagaimana cara pemotongan ternak dan penanganan karkas. Kesalahan dalam penanganan scjak persiapan akan merusak kualitas daging (Hafid, 1998).

Penanganan pasca pemotongan yang dapat dilakukan adalah aging atau pelayuan (biasa juga discbut conditioning). Kondisi selama pelayuan ini sangat mempengaruhi sifat-sifat organoleptiknya. Selama proses pelayuan, daging disimpan pada suhu dingin. Enzim endogen dalam otot seperti CASF (CAF) dan catepsin D dan B akan berperan dalam mendegradasi protein myofibrilar (Abustam et al. 1993). Perbaikan keempukan yang terjadi selama proses aging tergantung pada temperatur dan lama penyimpanan. Pada temperatur $+1{ }^{6} \mathrm{C}$ peningkatan keempukan terjadi selama 15 han dan khususnya pada minggu kedua (Dumont, 1952 dalam Abustam et al. 1993). Lama penyimpanan tujuh hari pada suhu $4^{\circ} \mathrm{C}$ keempukannya mencapai $10 \%$, sedangkan hari ke 17 keempukan mencapai $31 \%$.

\section{Materi dan Metode}

Penclitian ini dilaksanakan di Laboratorium Teknologi Hasil Pertanian Fakultas Pertanian Universitas Haluoleo Kendari dan berlangsung pada bulan April 2005.

Bahan yang digunakan dalam penelitian ini adalah daging sapi Bali betina berumur sekitar 3 tahun yang diperoleh dari pola pemeliharaan tradisional yang di potong di numah potong hewan. Sampel daging yang diambil berasal dari otot Longissimus dorsi (LD), Semitendinosus (ST), Pectoralis propundus (PP), yang masing-masing mewakili otot dengan kealotan rendah (empuk), kealotan sedang dan kealotan tinggi (alot).

Alat yang digunakan adalah: lemari es, termometer, timbangan anatitik, plastik polietilena, pisau, baskom, kompor dan alat tulis menulis. 
Penelitian ini dibagi dalam dua tahap yaitu penelitian pendahuluan dan penelitian utama. Penelitian pendahuluan dilakukan untuk pembiasaan panelis dan untuk menentukan besamya suhu dan lamanya waktu yang digunakan untuk perebusan sehingga diperoleh sampel yang cukup kekerasannya untuk dipotong-potong menjadi sub sampel dalam pengujian sclanjutnya, Pelayuan dilakukan pada suhu $2^{\circ} \mathrm{C}$ dengan menggunakan lomaries:

Sampel yang digunakan untuk pengujian harus dipisahkan dari jaringan ikat dan lemak yang terkait. Berat sampel daging yang digunakan 250 gram. Setiap sampel dimasukkan dalam plastik polictilena yang telah diberi label. Label yang diberikan disesuaikan dengan kombinasi perlakuan yang diterapkan.Sampel dimasukkan ke bagian ujung kantong plastik kemudian dilipat memanjang dan diklip sehingga tidak terjadi kontak langsung antara daging dengan air sesuaipctunjuk Soeparno (1998).

Metode yang digunakan dalam penelitian sesuai petunjuk Commonwealth Scientific and Industrial Research Organization (CSIRO) maupun Meat Research Laboratory Australia, sampel direbus dalam penangas air pada suhu $80^{\circ} \mathrm{C}$ dan waktu selama 30 menit. Setelah itu sampel didinginkan sampai mencapai suhu ruang dan disimpan pada suhu $0-5^{\circ} \mathrm{C}$.

Tabel 1. Skor hedonik untuk uji kualitas daging (Hedonic score of meat quality test)

\begin{tabular}{lcl}
\hline $\begin{array}{l}\text { Evaluasi sensori } \\
\text { (Censor evaluation) }\end{array}$ & $\begin{array}{c}\text { Skala hedonik } \\
\text { (Hedonic scala) }\end{array}$ & \multicolumn{1}{c}{ Kriteria (Criteria) } \\
\hline Keempukan & I & Sangat empuk (extremely tender) \\
(Tenderness) & 2 & Empuk (slightly tender) \\
& 3 & Keempukan Sedang (neither tough or tender) \\
& 4 & Alot (slightly tough) \\
\hline Warna (Color) & 5 & Sangat alot (extremly tough) \\
& 1 & Merah muda (brownish pink) \\
& 2 & Merah cerah (bright cherry red) \\
& 3 & Merah (red) \\
\hline Cita rasa (Flavor) & 4 & Merah tua (dark red) \\
& 5 & Coklat (brown) \\
& 1 & Sangat disukai (like extremely) \\
& 2 & Disukai (like a little) \\
& 3 & Cukup disukai (neither like or distike) \\
& 4 & Tidak disukai (dislike a little) \\
& 5 & Sangat tidak disukai (dislike extremely). \\
\hline Rasa (Taste) & 1 & Sangat disukai (like extremely) \\
& 2 & Disukai (like a little) \\
& 3 & Cukup disukai (neither like or dislike) \\
& 4 & Tidak disukai (dislike a little) \\
& 5 & Sangat tidak disukai (dislike extremely). \\
\hline Kesan Jus (Juiceness) & 1 & Sangat berjus (extremely juiciness) \\
& 2 & Berjus (slightly juiciness) \\
& 3 & Sedang (normally) \\
& 4 & Kering (dry) \\
& 5 & Sangat kering (extremely dry) \\
\hline
\end{tabular}

Sumber (Source) : Hafid, et al. (2000) 


\section{Rancangan percobaan}

Metoda yang digunakan dalam penelitian ini adalah Rancangan Acak Lengkap (RAL) pola faktorial $5 \times 3$ dengan 4 kali ulangan (Steel dan Torric, 1980) dengan taraf perlakuan sebagai berikut: Faktor A terdiri atas lima taraf yaitu; $\mathrm{Al}=\operatorname{lama}$ pelayuan nol hari, $\mathrm{A} 2$ = lama pelayuan tiga hari, $\mathrm{A} 3=$ lama pelayuan empat hari, $\mathrm{A} 4=$ tama pelayuan lima hari dan $\mathrm{A} 5=$ lama pelayuan enam hari. Faktor B terdiri atas tiga taraf yaitu: $\mathrm{B1}=$ Otot Longissimus dorsi (LD), B2 = Otot Semitendinosus $($ ST), B3 = Otot Pectoralis propundus (PP). Model matematis dari rancangan yang digunakan adalah sebagai berikut:

$$
\begin{aligned}
& i=1,2, \ldots, 5 \\
& j=1,2,3 \\
& k=1,2,3,4 \\
& \text { keterangan: }
\end{aligned}
$$

$$
\mathrm{Yijk}=\mathrm{H}+\mathrm{A} \mathbf{i}+\mathrm{Bj}+(\mathrm{AB}) \mathrm{j} \mathbf{j}+\varepsilon \mathbf{j} \mathrm{jk}
$$

$$
\begin{aligned}
\text { Yijk }= & \text { Hasil pengamatan } \\
\mathrm{u}= & \text { Rata-rata keseluruhan } \\
& \text { pengamatan } \\
\mathrm{Ai}= & \text { Pengaruh lama pelayuan } \\
\mathrm{Bj}= & \text { Pengaruh jenis otot ke-j } \\
(\mathrm{AB}) \mathrm{ij}= & \text { Pengaruh interaksi lama } \\
& \text { pelayuan ke-i terhadap jenis } \\
& \text { otot ke-j } \\
\varepsilon \mathrm{ijk}= & \text { Kesalahan pengamatan } \\
& (\text { error })
\end{aligned}
$$

Jika perlakuan menunjukkan pengaruh yang nyata, maka dilanjutkan dengan Uji Beda Nyata Terkecil (BNT).

Pengujian terhadap keempukan, warna, cita rasa, flavor, juiciness (kesan jus daging) dilakukan secara organoleptik (panel test) dilakukan olch 515 orang panclis terlatih sesuai peturjuk Soekarto dan Hubeis (1992). Kritcria penilaian menggunakan skala hedonik pada masing-masing skala lima titik sesuai petunjuk Rahayu (1997).

\section{Hasil dan Pembahasan}

Rata-rata skor hedonik pengujian panelis terhadap persentase keempukan daging sapi Bali pada lama pelayuan dan jenis otot yang berbeda dapat dilihat pada Tabel 2 .
Hasil analisis statistik menunjukkan bahwa interaksi antara lama pelayuan dan jenis otot, maupun lama pelayuan dan jenis otot secara mandiri berpengaruh sangat nyata $(P<0.01)$ terhadap keempukan daging sapi. Uji beda nyata jujur menunjukkan bahwa keempukan tertinggi diperoleh pada kombinasi otot longissimus dorsi dengan lama pelayuan lima dan enam hari, masing-masing skor panelis 1,34 dan 1,36 sangat nyata berbeda dengan kombinasi lainnya pada otot yang sama, otot semitendinosus dan otot pectoralis propundus pada lama pelayuan antara $0-6$ hari.

Tingkat keempukan terendah dijumpai pada kombinasi otot pectoralis propundus dengan lama pelayuan nol hari (kontrol). Hal ini sesuai dengan Abustam et al. (1993) yang menyatakan bahwa otot longissimus dorsi merupakan otot yang paling empuk, kemudian otot semitendinostus mempunyai kecmpukan sedang dan otot yang paling alot adalah otot Pectoralis propundus. Selanjutnya Soeparno (1998) menjelaskan bahwa tingkat keempukan otot dapat diperbaiki dengan pelayuan (aging) karena adanya enzim catepsin dan CAF yang dapat mendegradasi jaringan miofibriler otot sehingga otot akan menjadi lebih empuk. Kondisi ini telah pula dibuktikan oleh Hafid, et al. (2000).

Rata-rata skor hedonik pengujian panelis terhadap warna daging sapi Bali pada lama pelayuan dan jenis otot yang berbeda dapat dilihat pada Tabel 3. Hasil amalisis statistik menunjukkan bahwa interaksi antara lama pelayuan dan jenis otot mapun lama pelayuan berpengaruh sangat nyata $(P<0.01)$ terhadap warna daging sapi. Sementara jenis otot secara mandiri menunjukkan pengaruh nyata $(\mathrm{P}<0.05)$ terhadap wama daging. Uji beda nyata jujur menunjukkan bahwa kombinasi otot Longissimus dorsi dengan lama pelayuan nol dan tiga hari, kombinasi otot semitendinosus dengan lama pelayuan nol dan empat hari serta kombinasi otot Pectoralis propundus dengan lama pelayuan nol dan lima hari (masing-masing dengan skor panelis 3,0), kombinasi otot Longissimus dorsi dengan lama pelayuan empat dar tima hari, kombinasi otot semitendinosus dengan lama pelayuan 
tiga, lima dan enam hari maupun kombinasi otot Pectoralis propundus dengan lama pelayuan tiga dan empat hari (masing-masing dengan skor panelis 2,0 ) sangat nyata menampakkan warna merah cerah dibandingkan đengan kombinasi lainnya. Warnu otot yang tampak antara merah cerah dan merah pada kombinasi otot Longissimus dorsi dengan lama pelayuan enam hari.

Kecerahan warna daging akan memberikan daya pikat (attractiveness) terhadap konsumen. Perbedaan ini mungkin disebabkan oleh adanya perbedaan kadar pigmen mioglobin daging, dan terbentuknya mioglobio yang lebih banyak dipengaruhi oleh aktivitas urat daging (Lawrie, 2003). Otot Pectoralis propundus yang terletak antara dada dan kaki depan mempunyai aktivitas lebih tinggi daripada otot semitendinosus pada paha (pinggul) belakang maupun otot longissimus dorsi yang kurang aktif pada punggung.

Rata-rata skor hedonik pengujian panelis terhadap cita rasa daging sapi Bali pada lama pelayuan dan jenis otot yang berbeda dapat dilihat pada Tabel 4. Hasil analisis statistik menunjukkan bahwa interaksi antara lama pelayuan dan jenis otot tidak berpengarah nyata terhadap cita rasa daging sapi. Secara mandiri, lama pelayuan nyata mempengaruhi citi rasa daging sapi $(P<0.05)$, sedangkan jenis otot secara mandir berpengaruh sangat nyata terhadap cita rasa daging sapi $(\mathrm{P}<0.01)$. Uji beda nyata jujur menumukkan bahwa lama pelayuan empat, lima dan enam hari dengan skor panelis masing-masing 1.92; 2.11 dan 1. 96 nуata "lebih disukaj

Tabel 2. Skor hedonik keempukan daging (Hedonic score of meat tenderness)

\begin{tabular}{|c|c|c|c|c|c|c|}
\hline \multirow{2}{*}{$\begin{array}{l}\text { Jenis otot (Type of } \\
\text { muscle) }\end{array}$} & \multicolumn{5}{|c|}{ Lama pelayuan (hari) (Aging time (day)) } & \multirow{2}{*}{$\begin{array}{l}\text { Rerats } \\
\text { (Average) }\end{array}$} \\
\hline & 0 & 3 & 4 & 5 & 6 & \\
\hline Longissimus dorsi & $1.89^{62}$ & $2.00^{.15}$ & $1.58^{\text {hic }}$ & $1.34^{42}$ & $1.36^{2}$ & $1.63^{\prime}$ \\
\hline Semitendinosu; & $2.18^{k}$ & $2.25^{\mathrm{ni}}$ & $1.59^{c 2}$ & $2.59^{\mathrm{bl}}$ & $2.19^{\text {h1 }}$ & $2.19^{\prime}$ \\
\hline Pectoralis propunilus & $3.14^{*}$ & $2.08^{6}$ & $1.69^{7}$ & $2.32^{i}$ & $2.05^{n}$ & $2.25^{3}$ \\
\hline Rerata (Averoge) & $2.40^{11}$ & $2.11^{\mathrm{N}^{2}}$ & $1.62^{6}$ & $2.08^{22}$ & $1.87^{\circ}$ & \\
\hline
\end{tabular}

7) Superskrip yang berbeda pada baris dan kolom yang sama menunjukkan perbedaan yang nyata (Different superscripts at the same row and colomn including significant differences). Superskrip huruf menunjukkan beda nyata dan superskrip angka menunjukkan beda sangat nyata (Letter superscripts including high significant diffenences and number superscripts inchuding significant differences),

Tabel 3. Skor hedonik wama daging (Hedonik score of meat color)

\begin{tabular}{|c|c|c|c|c|c|c|}
\hline \multirow{2}{*}{$\begin{array}{l}\text { Jenis otot (Type of } \\
\text { muscle) }\end{array}$} & \multicolumn{5}{|c|}{ Lama pelayuan (hari) (Aging time (day)) } & \multirow{2}{*}{$\begin{array}{l}\text { Rerata } \\
\text { (Average) }\end{array}$} \\
\hline & 0 & 3 & 4 & 5 & 6 & \\
\hline Longissimus dorsi & $3.00^{n}$ & $3.00^{x}$ & $2.00^{c}$ & $2.00^{2}$ & $2.50^{3}$ & $2.50^{1}$ \\
\hline Semitendinosus & $3.00^{A}$ & $2.00^{\mathrm{C}}$ & $3.00^{x}$ & $2.00^{\circ}$ & $2.00^{\mathrm{C}}$ & $2.40^{2}$ \\
\hline Pectoralis propundus & $3.00^{\wedge}$ & $2.00^{\mathrm{C}}$ & $2.00^{\mathrm{c}}$ & $3.00^{\wedge}$ & $2.00^{\mathrm{c}}$ & $2.40^{2}$ \\
\hline Rerata (Average) & $3.00^{3}$ & $2.33^{\text {म }}$ & $2.33^{\text {b! }}$ & $2.33^{4}$ & $2.17^{2}$ & \\
\hline
\end{tabular}

*) Supcrskrip yang berbeda pada baris dan kolom yang sama menunjukkan perbedaan yang nyata (Different superscripts at the same row and colomn including significant differences). Superskrip huruf menunjukkan beda nyata dan superskrip angka memunjukkan beda sangat nyath (Letter superscripts inchuding high significant differences and number superscripts including significant differences). 
Tabel 4. Skor hedonik cita rasa daging (Hedonic score of meat taste)

\begin{tabular}{lcccccc}
\hline \multirow{2}{*}{$\begin{array}{l}\text { Jenis otot (Type of } \\
\text { muscle) }\end{array}$} & \multicolumn{5}{c}{ Lama pelayuan (hari) (Aging time (day)) } & Rerata \\
\cline { 2 - 6 } & 0 & 3 & 4 & 5 & 6 & (Average) \\
\hline Longissimus dorsi & 2.07 & 2.30 & 1.84 & 1.68 & 1.52 & $1.88^{\circ}$ \\
Semitendinosus & 2.22 & 2.40 & 1.81 & 2.55 & 2.14 & $2.22^{11}$ \\
Pectoralis propundus & 2.68 & 2.28 & 2.11 & 2.11 & 2.22 & $2.29^{\circ}$ \\
\hline Rerata (Average) & 2.32 & $2.33^{7}$ & $1.92^{2}$ & $2.11^{11}$ & $1.96^{2}$ & \\
\hline
\end{tabular}

*) Superskrip yang berbeda pada baris dan kolom yang sama menunjukkan perbedaan yang nyata (Different superscripts at the same row and colomn including significant differences). Superskrip hurul menunjukkan beda nyata dan superskrip angka menunjukkan beda sangat nyata (Letter superscripts including high significant differences and number superscripts including significant differences).

\section{$1.92 ; 2.11$ dan 1.96 nyata "lebih disukai} panelis" dibandingkan lama pelayuan dibawah 4 hari, Sementara itu otot longissimus dorsi sangat nyata "lebih disukai panclis" dibandingkan otot semitendinosus dan Pectoralis propundus.

Adanya perbedaan ini menunjukkan bahwa semakin lama pelayuan akan mampu meningkatkan cita rasa maupun flavor daging. Hal ini sesuai dengan pendapat Soeparno (1998) yang menyatakan bahwa cita rasa dan flavor daging masak sangat dipengaruhi oleh lama waktu penyimpanan (pelayuan) dan kondisi penyimpanan daging setelah dipotong. Sementara tingginya penilaian terhadap cita rasa otot longissimus dorsi kemungkinan disebabkan adanya kandungan lemak intramuskuler pada ofot ini. Menurut Callow (1962) dalam Lawric, (2003) jenis otot longissimus dorsi mengandung lemak lebih tinggi dibandingkan jenis otot lainnya.

Rata-rats skor hedonik pengujian panelis terhadap flavor daging sapi Bali pada lama pelayuan dan jertis otot yang berbeda dapat dilihat pada Tabel 5.

Hasil analisis statistik menunjukkan bahwa interaksi antara lama pelayuan dan jenis otot, lama pelayuan maupun jenis otot secara mandiri berpenganth sangat nyata $(\mathrm{P}<0.01)$ terhadap flavor daging. Uji beda nyata jujur menunjukkan bahwa kombinasi otot longissimus dorsi dengan lama pelayuan lima dan enam hari sangat nyata memberikan flavor "lebih disenangi" oleh para panelis (skor panelis masing-masing 1.53 dan 1.65 ) dibandingkan dengan kombinasi lainnya. Skor flavor terendah "agak disukai") diperoleh pada kombinasi otot semitendinosus dengan lama pelayuan tiga dan lima hari (masing-masing dengan skor panelis 2.73) demikian pula dengan kombinasi otot pectoralis propundus. dengan lama pelayuan nol dan lima hari (skor panelis 2.57 dan 2.39)

$\mathrm{Hal}$ ini disebabkan karena otot. longissimus dorsi mempunyai tekstur lebih halus dan rapat dibandingkan kedua jenis otot lainnya. Menurut Aberle et al., (2001) flavor daging melibatkan tekstur di samping bau, rasa, temperatur dan $\mathrm{pH}$. Sementara itu Blatzer (1971) dalam Hafid et al. (2000) menyatakan bahwa kandungan lemak daging akan mempengaruhi favor dan cita rasa daging masak. Hal ini disebabkan karena otot longissimus dorsi mengandung lemak lebih tinggi (Callow, 1962 dalam Lawrie, 2003) dibandingkan otot semitendinosus dan pectoralis propundus. Disamping itu peningkatan flavor selama pelayuan dapat berhubungan dengan pemecahan nukleotida. ADP dan AMP masing-masing mengalami defosforilasi dan deaminasi menjadi asam inosinat (IMP) yang selanjutnya mengalami defosforilasi menjadi inosin atau selanjutinya dipecah menjadi ribosa dan hipoksantin. Asam inosinat, gula ribosa, glikoprotein dan asamasam amino merupakan senyawa aktif yang menentukan flavor daging (Tsai, et al. 1972 dalam Soeparno, 1998). 
Tabel 5. Skor hedonik aroma daging (Hedonic score of meat flavor)

\begin{tabular}{|c|c|c|c|c|c|c|}
\hline \multirow{2}{*}{$\begin{array}{l}\text { Jenis otot (Type of } \\
\text { muscle) }\end{array}$} & \multicolumn{5}{|c|}{ Lama pelayuan (hari) (Aging time (day)) } & \multirow{2}{*}{$\begin{array}{l}\text { Rerata } \\
\text { (Average) }\end{array}$} \\
\hline & 0 & 3 & 4 & 5 & 6 & \\
\hline Longissimus dorsi & $2.14^{h}$ & $2.33^{7}$ & $1.95^{1}$ & $1.53^{n}$ & $1.65^{2}$ & $1.92^{2}$ \\
\hline Semitendinosus: & $2.14^{\hbar}$ & $2.73^{\mathrm{b2}}$ & $2.03^{\mathrm{b}}$ & $2.73^{k 2}$ & $2.17^{\mathrm{t}}$ & $2.36^{2}$ \\
\hline Pectoralis propundus & $2.57^{\circ}$ & $2.30^{2}$ & $2.28^{2}$ & $2.39^{6}$ & $2.02^{\prime}$ & $2.31^{b}$ \\
\hline Rerata (Average) & $2.28^{x}$ & $2.45^{\prime}$ & $2.08^{\mathrm{b}}$ & $2.21^{\mathrm{h}}$ & $1.95^{a}$ & \\
\hline F) Superskrip yang be & eda pad & is dan & nyang & $\frac{2.21}{\text { a ment }}$ cluding & $\begin{array}{l}\frac{1.93}{\mathrm{k} k a n} \mathrm{pe} \\
\text { nifican }\end{array}$ & \\
\hline
\end{tabular}

Tabel 6. Skor bedonik kesan jus daging (Hedonic score of meat juiciness)

\begin{tabular}{|c|c|c|c|c|c|c|}
\hline \multirow{2}{*}{$\begin{array}{l}\text { Jenis otot (Type of } \\
\text { muscle) }\end{array}$} & \multicolumn{5}{|c|}{ Lama pelayuan (hari) (Aging time (day)) } & \multirow{2}{*}{$\begin{array}{l}\text { Rerata } \\
\text { (Average) }\end{array}$} \\
\hline & 0 & 3 & 4 & 5 & 6 & \\
\hline Longissimus dorsi & $2.60^{22}$ & $2.80^{\mathrm{E}}$ & $2.91^{2}$ & $3.09^{3}$ & $2.61^{H r}$ & $2.80^{27}$ \\
\hline & $2.97^{\circ}$ & $2.77^{4}$ & $2.86^{\mathrm{b}}$ & $3.16^{\mathrm{tz}}$ & $2.94^{t}$ & $2,94^{\prime}$ \\
\hline Pectoralis propundus & $3.57^{\text {at }}$ & $3.00^{b}$ & $2.99^{k}$ & $3.11^{2}$ & $2.91^{\mathrm{i}}$ & $3.11^{\text {n22 }}$ \\
\hline Rerata (Average) & $3.04^{2}$ & $2.86^{\circ}$ & $2.92^{2}$ & $3.12^{6}$ & $1.82^{\mathrm{t}}$ & \\
\hline
\end{tabular}

*) Superskrip yang berbeda pada baris dan kolom yang sama menunjukkan perbedaan yang nyata (Different superscripts at the same row and colom including significant differences). Supersknip huruf menunjukkan beda nyata dan superskrip angka menunjukkan beda sangat nyata (Letter superscripts including high significant differences and number superscripts including significant differences).

Hasil analisis statistik menunjukkan bahwa interaksi antara lama pelayuan dan jenis otot, maupun lama pelayuan dan jenis otot secara mandir berpengaruh sangat nyata $(\mathrm{P}<0.01)$ terhadap kualitas juiciness daging sapi. Uji beda nyata jujur menunjukkan bahwa kombinasi otot Iongissimus dorsi dengan lama pelayuan not, tiga, empat dan enam hari sangat nyata memberikan kesan agak berminyak (juicy) masing-masing dengan skor panelis 2,$60 ; 2,80 ; 2,91$ dan 3,61 dibandingkan dengan kombinasi lainnya. Kesan tidak berminyak (kering) diperoleh pada kombinasi otot semitendinosus dengan lama pelaynan lima hari (skor panelis 3.16) dan kombinasi otot pectoralis propundiss dengan lama pelayuan nol hati (kontrol), skor panelis 3.57).

Hal ini menunjukkan bahwa otot longissimus dorsi cenderung memberikan kesan berminyak (juicy) dibandingkan otot semitendinosus dan pectoralis propundus. Hal ini mungkin disebabkan oleh adanya kandungan lemak intramuskuler (marbling) yang lebih tinggi pada otot longissimus dorsi, scperti telah disebutkan oleh Blatzer (1971) dalam Hafid, et al. (2000). Disamping itu, perbedaan yang diperoleh dapat dihubungkan dengan dengan besarnya derajat susut masak (cooking loss) dari daging. Dalam hal ini susut masak berkisar antara $19.74 \%-24.57 \%$ pada otot longissimus dorsi, $19.79 \%-27.12 \%$ pada otot semitendinosus dan $20.00 \%-27.12 \%$ pada otot pectoralis propundus, pada lama pelayuan nol sampai enam hari.

Kesan jus daging (juiciness) mempunyai hubungan crat dengan susut masak. Lebih dari $70 \%$ variasi kadar jus daging steer disebabkan olch susut masak 
yang tinggi (Soeparno, 1998), menyatakan hahwa kesan jus daging merupakan kombinasi dari dus pengaruh yaitu kesan cairan yang dibebaskan selama pengunyahan dan salivasi yang diproduksi oleh faktor-faktor flavor seperti lemak intramuskuler selama pengunyahan di mana cairan terperas keluar karena adanya sentrifugasi dan tekanan. Di samping itu lemak intramuskuler merupakan stimulan terhadap salivasi. Swatland (1984) menyatakan bahwa lemak intramuskuler berkorelasi dengan jus daging sampai dengan $2 \%$ lemak dalam jus. Dengan demikian daging yang bcrkualitas baik secara relatif mengandung lebih banyak jus daripada daging yang berkualitas rendah disebabkan oleh perbedaan kadar lemak intramuskulernya (marbling).

\section{Kesimpulan}

Kombinasi lama pelayuan enam hari dengan otot Longissimus dorsi mempelihatkan keempukan, warna, flavor dan kesan jus daging yang lebih baik. Lama pelayuan sampai enam hari masib menunjukkan sifat organoleptik yang disenangi panelis. Otot Longgisimus dorsi mempunyai kualitas organoleptik lebih baik dari pada otot Semitendinosus dan otot Pectoralis propiundus.

\section{Daftar Pustaka}

Aberle, E.D., Forrest, JC, Gerrard, DE, and Mills EW, 2001. Principles of Meat Science. W.H. Freman and Company, San Fransisco.
Abustam, E, Muslimin,L,, dan Likadja, J.Ch,, 1993. Peranan pelayuan (aging) terhadap mutu daging sapi Bali yang dipelihara secara tradisional dan dengan sistem penggemukan. Laporan Penelitian Fakultas Peternakan Universitas Hasanuddin, Ujung Pandang.

Hafid, H, 1998. Kinerja produksi sapi australian commercial cross yang dipelihara secara feedlot dengan kondisi bakalan dan lama penggemukan berbeda. Tesis Program Pascasarjana IPB, Bogor.

Hafid, H., Nuraini dan A. Syam., 2000. Kualitas daging kambing lokal dengan metoda pelayuan dan pemasakan serta umur yang berbeda. Laporan Penelitian Fakultas Pertanian Universitas Haluoleo, Kendari.

Lawrie, R.A., 2003. Ilmu Daging. Terjemahan Aminuddin Parakkasi. Universitas Indonesia Press, Jakarta.

Rahayu, W.P. 1997. Penuntun Praktikum Penilaian Organoleptik. Program Studi Supervisor Jaminan Mutu Pangan. Jurusan TPG-Fateta IPB, Bogor.

Soekarto, S.T, dan M. Hubeis. 1992. Petunjuk Laboratorium Metode Penelitian Indrawi. Pusat Antar Universitas Pangan dan Gizi. IPB, Bogor.

Soeparno. 1998. Ilmu dan Teknologi Daging. Gadjah Mada University Press, Yogyakarta.

Steel, R.G.D., and J.H. Torrie, 1980. Principles and Procedures of Statistics. A Biometrical Approach. MC Graw Hill Book Co,, Inc New York 